Special section: The Future of Tanah Papua - Towards Multi-disciplinarity on Adat, Biodiversity, and Sustainable Development

Research Article

\title{
An annotated bird checklist for Gam island, Raja Ampat, including field notes on species monitoring and conservation
}

\author{
Julian Schrader ${ }^{1,2, *}$, Christoph Parsch ${ }^{1,3, *}$, Soetjipto Moeljono ${ }^{4}$, John D. Kalor ${ }^{5}$, Tim Hofmann ${ }^{6}$, \\ Christoph Weinrich7, Fabian Mühlberger ${ }^{7}$, Christina Stinn ${ }^{7}$, Michael Mühlenberg ${ }^{7}$, Cornelia \\ Sattler ${ }^{2}$ \\ ${ }^{1}$ Biodiversity, Macroecology and Biogeography, Faculty for Forestry and Forest Ecology, University of \\ Goettingen, Goettingen, Germany. \\ ${ }^{2}$ Department of Community Ecology, UFZ - Helmholtz Centre for Environmental Research, Theodor-Lieser- \\ Straße 4, 06120 Halle, Germany. \\ ${ }^{3}$ Centre of Biodiversity and Sustainable Land Use (CBL), University of Goettingen, Goettingen, Germany \\ ${ }^{4}$ Faculty of Forestry, University of Papua, 98314 Manokwari, Papua Barat, Indonesia. \\ ${ }^{5}$ Department of Marine Sciences and Fisheries, University of Cenderawasih, Jayapura, Papua, Indonesia. \\ ${ }^{6}$ Cheetah Conservation Fund, PO Box 1755 Otjiwarongo, Namibia. \\ 7 Conservation Biology, Workgroup on Endangered Species, University of Goettingen, Goettingen, Germany. \\ *These authors contributed equally to this work. Correspondence: Julian Schrader, E-mail: jschrad@uni- \\ goettingen.de; Christoph Parsch, E-mail: parsch@posteo.net
}

\begin{abstract}
Species checklists are a fundamental component of biodiversity research. They advance the understanding of species distributions and habitat preferences, thus reducing gaps of knowledge in geographical occurrences of species. Especially in light of the limited availability of data on species distributions for Tanah Papua, an increasing scientific focus on the region is crucial to foster and refine the knowledge of species occurrences and to inform potential conservation planning efforts. Despite a strong focus on conservation of Raja Ampat's marine areas, surprisingly few studies have focused on the terrestrial biodiversity of the archipelago. As a consequence, detailed species checklists for the region are largely missing. Here, we provide a preliminary bird species checklist for the island of Gam and its surrounding islands, located in central Raja Ampat. During nine sampling periods between 2013 and 2019, we recorded 132 bird species in six distinct habitat types. Of the detected species, six are considered threatened by IUCN Red List criteria. We further recorded three new species (Black Fantail, Boyer's Cuckooshrike, and Bare-eyed Rail) for Gam Island, thereby expanding their known extent of occurrence.
\end{abstract}

Keywords: Birds, Checklist, Conservation, Gam Island, Raja Ampat, Papua Barat, New Guinea

Abstrak: Daftar jenis merupakan komponen dasar penelitian keanekaragaman hayati. Hal itu membantu mengembangkan pemahaman tentang distribusi jenis dan preferensi habitat, sehingga mengurangi kesenjangan pengetahuan tentang keberadaan jenis secara geografis. Terutama mengingat terbatasnya ketersediaan data tentang distribusi jenis untuk Tanah Papua, peningkatan fokus ilmiah di wilayah ini sangat penting untuk membantu mengembangkan dan menyaring pengetahuan dari keberadaan jenis dan untuk menginformasikan perencanaan konservasi yang tepat. Meskipun memiliki fokus yang kuat tentang konservasi di wilayah laut Raja Ampat, namun secara mengejutkan sangat sedikit studi yang berfokus pada keanekaragaman hayati terestrial di kepulauan tersebut. Akibatnya, data terperinci tentang daftar jenis sebagian besar hilang. Di sini, kami menyediakan data awal tenatang daftar jenis burung untuk pulau Gam dan pulau-pulau di sekitarnya, yang terletak di bagian tengah kepulauan Raja Ampat. Selama sembilan kali pengambilan contoh antara tahun 2013 sampai 2019, kami mencatat 132 jenis burung dalam enam habitat yang berbeda. Dari jenis yang diketahui, enam diantaranya termasuk terancam, yang menurut kriteria daftar merah dari IUCN. Selanjutnya, kami mencatat tiga jenis baru di pulau Gam, dengan demikian memperluas tingkat pengetahuan tentang keberadaan jenis-jenis tersebut.

Keywords: Burung, Daftar Jenis, Konservasi, Pulau Gam, Raja Ampat, Papua Barat. 


\section{Introduction}

The island of New Guinea features high species endemism and a unique terrestrial and marine biodiversity (Roberts et al., 2002; Orme et al., 2005). Birds-of-paradise, Bowerbirds, and Cassowaries are just few examples of the avifauna native to New Guinea. Despite being one of the last tropical wilderness areas (Mittermeier et al., 2003), scientific focus on New Guinea with regards to biodiversity research falls behind other tropical regions (Allison, 2007; Mack \& Dumbacher, 2007; Meyer et al., 2015).

The eastern parts of New Guinea (Papua New Guinea) are relatively well-studied, resulting, for instance, in detailed accounts of bird species occurrences (e.g., Diamond, 1972; Diamond \& Lecroy, 1979; Freeman \& Class Freeman, 2014). However, biodiversity patterns for Tanah Papua - the Indonesian part of New Guinea - are less well known (Meyer et al., 2015; but see e.g., Diamond \& Bishop, 2015). To our knowledge, no expert bird checklists exist for the major satellite islands of Tanah Papua, including Waigeo, Misool, Batanta, Japen, or Biak. This has resulted in considerable data gaps for Tanah Papua in terms of species distributions, habitat associations, breeding behavior, and species ecology in general (Beehler \& Pratt, 2016; Noske et al., 2016). Particularly in the face of Tanah Papua's accelerating land-use change (Austin et al., 2017) and ambitious political pledge to increase conservation efforts in Tanah Papua (Cámara-Leret et al., 2019a), a stronger scientific focus on species distributions becomes increasingly important. This basic knowledge is an essential requisite to quantify biodiversity values of specific regions as well as to understand potential impacts of global warming (as shown by, e.g., Freeman \& Class Freeman, 2014) and thus to prioritize, inter alia, species-rich sites for conservation actions (Cámara-Leret et al., 2019b).

One of the most biologically diverse regions in Tanah Papua is the Raja Ampat archipelago (Beehler, 2007), which includes the westernmost satellite islands of New Guinea. Bordering the two zoogeographical realms of Wallacea and Australia, the biodiversity of Raja Ampat includes species of Asian and Australian origin (Kreft \& Jetz, 2010). For instance, many bird species either have their most easterly (species shared with Maluku islands) or most westerly (species shared with mainland New Guinea) occurrences in Raja Ampat (Heads 2002). The unique avifauna of the region is based on a complex geological and biogeographic history (Mack \& Dumbacher, 2007). The Raja Ampat archipelago features about 1600 land-bridge and oceanic islands of different sizes, ages, and degrees of isolation (Djarwoto et al., 2013). It also possesses many different ecosystems, including lowland and mountain rainforests, mangrove forests and limestone karst, as well as marine habitats such as coral reefs, atolls, and pelagic zones (Takeuchi, 2003; Beehler, 2007). While there is a strong conservation focus on Raja Ampat's marine areas (McLeod et al., 2009), surprisingly little is known about its terrestrial biodiversity. For birds, detailed checklists are missing for most of the Raja Ampat islands.

Here, we provide a preliminary bird species checklist for Gam Island and its smaller surrounding islands in central Raja Ampat. Our main aim was to document the avifauna of the region and to provide information on species habitat preferences and their current conservation status. We identify gaps in species occurrences on existing distribution maps and in databases and further discuss current conservation threats and opportunities. This species checklist can be used as a baseline reference for future monitoring schemes in the region.

\section{Methods}

\subsection{Study site}

Our checklist focuses on Gam Island $\left(200 \mathrm{~km}^{2}\right)$ and its surrounding islands located in central Raja Ampat. The archipelago is located close to the equator $\left(130^{\circ} 34^{\prime} \mathrm{E} ; 0^{\circ} 31^{\prime} \mathrm{S}\right)$ in the west of Indonesia's province Papua Barat (Figure 1a). The climate is tropical without pronounced seasonality (mean annual precipitation $2678 \mathrm{~mm}$; mean annual temperature $27.2^{\circ} \mathrm{C}$; www.worldclim.org). Gam 
Island comprises tropical lowland rainforest, mostly on limestone substrate (Takeuchi, 2002), with numerous small islands scattered along its coastline (Schrader et al., 2019a). Its coastline also harbors extensive mangrove forests in bays and estuaries. Only a few villages exist on Gam, where local communities mainly depend on fishing and rapidly expanding tourism activities to sustain their livelihoods. Waigeo, Raja Ampat's largest island, is located to the north and east of Gam Island and is separated by a narrow sea water channel. A number of offshore islands lie in the south and west of Gam Island as well as sandy shoals, which are submerged during high tide. We classified and surveyed six major habitat types and ecosystems in the study region:

1. Secondary growth forest and anthropogenic sites: this habitat type includes villages and disturbed habitats on Gam Island. Disturbed sites were mainly clear-cut and used as gardens or were fallow land. These sites were mostly located in close vicinity to villages.

2. Forest: Tropical lowland forest comprises the most extensive ecosystem on Gam and covers its interior.

3. Mangroves: Extensive mangrove forests fringe the coastline of Gam. Denser and higher mangrove forests occur in estuaries, inlets, and shallow bays, which are dominated by Bruguiera-Rhizophora associations (Takeuchi, 2002).

4. Small islands: Numerous small islands - ranging in size from a few square meters to several hectares - line the coastline of Gam Island. Vegetation on these islets is dominated by woody plants and is in pristine condition without signs of anthropogenic disturbance. Coralline karst is the dominant substrate of these islands (Schrader et al., 2019b).

5. Offshore islands: All offshore islands are located at least five $\mathrm{km}$ from the islands of Gam or Waigeo. The offshore islands within the study region are predominantly covered by vegetation adapted to dry conditions. Vegetation includes limestone karst, dry forests, and scrubland (Takeuchi, 2002). The terrain on these islands ranges from sandy flats to ultrabasic serpentine and steep slopes (Takeuchi, 2003). Examples are the islands of Fam or Yeben Island (Figure 1b).

6. Open sea, sandbanks, and outer reefs: This habitat type includes all marine habitats. The sandbanks are submerged during high tide and do not support vegetation.

\subsection{Field sampling}

Our main aim was to document the avifauna of the region and to provide information on species habitat preferences and their current conservation status. We therefore performed opportunistic surveys in as many habitats and locations as possible. We conducted all bird species observations on and around the island of Gam (Figure 1b) between 2013 and 2019 during nine time periods. These periods were from October - November 2013 (eight weeks), October 2014 (three weeks), March - May 2015 (eight weeks), April 2016 (three weeks), June 2016 (four weeks), November - December 2016 (seven weeks), November 2017 (four weeks), February 2018 (three weeks), October - November 2018 (six weeks), and October 2019 (two weeks) (note that we did not sample in January and from July to September due to logistical constraints). We were based in Sawinggrai village on Gam Island during field work (Figure 1b) and recorded bird species every day during the sampling periods by sight using binoculars. Species that we could not immediately identify were photographed using telephoto lenses and identified later. Species observations on Gam Island were mostly conducted at dawn (5:30 AM to 7 AM) and dusk (5 PM to 6:30 PM). In addition, we conducted nocturnal surveys on Gam Island once per week. Small islands, offshore islands, and open ocean were mainly surveyed during day-time trips (approximately three surveys each week) due to difficult accessibility by boat. On Gam Island, we visited ten different locations across the island to record forest bird species (Figure 1b). All bird records were grouped into the above described habitat types. We counted the number of time periods each species was recorded in each habitat type as a species commonness or rarity index. An index of nine indicated that a 
species was observed during all time periods in a respective habitat type; an index of zero showed that the species was never observed in that habitat type.

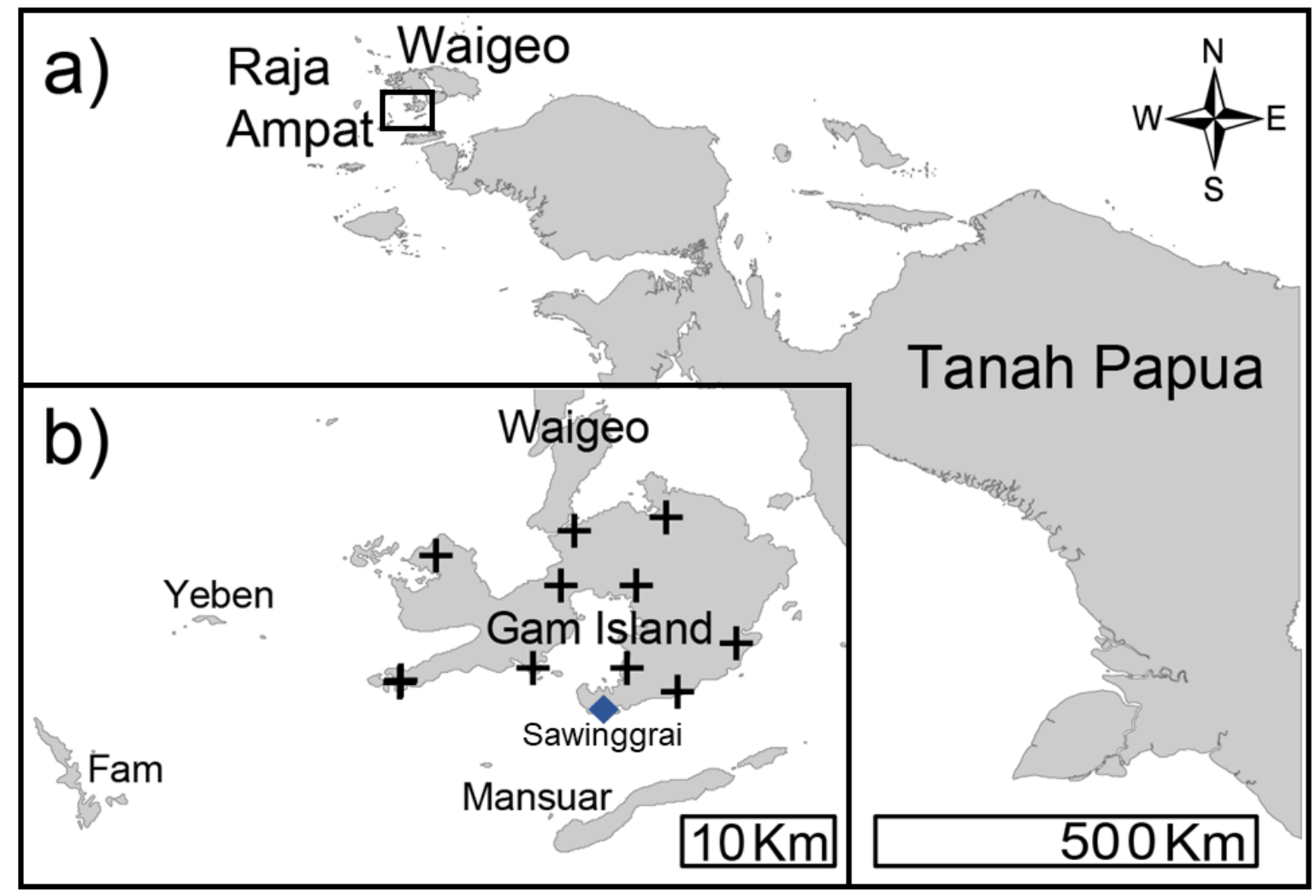

Figure 1. Map of (a) Tanah Papua and (b) the study region located in central Raja Ampat with surveyed offshore islands indicated in the map. Our research station in Sawinggrai village is indicated by blue rhombus and other sampling locations on Gam Island are indicated by $(+)$.

We identified all species using the field guides Birds of New Guinea (Pratt \& Beehler, 2015) and Birds of New Guinea: Including Bismarck Archipelago and Bougainville (Gregory, 2017). We based taxonomy on the online database of the Handbook of the Birds of the World (www.hbw.com). We retrieved the species conservation status from the IUCN Red List (www.iucnredlist.org). To assess whether the observed species had previously been recorded for Gam Island, we matched the observed records with the species distributions shown in the field guides Birds of New Guinea (Pratt \& Beehler, 2015), Birds of New Guinea: Including Bismarck Archipelago and Bougainville (Gregory, 2017), and with the online databases Handbook of the Birds of the World (www.hbw.com), Global Biodiversity Information Facility (www.gbif.org), BirdLife International (www.birdlife.org), eBird (www.ebird.org), and Map of Life (www.mol.org) (all online databases accessed in November 2019).

\section{Results}

We recorded 132 bird species from 48 families (Appendix Table A1). Fifty-seven species were recorded in a single habitat type: 25 species were only found in forests, 11 in secondary growth forest and anthropogenic modified habitats, six species on outer islands and sandbanks, and four species in mangroves. Five species were only found on small islands. Most species occurred in secondary growth and anthropogenic modified habitats and forests (68 species each), followed by small islands ( 52 species), mangrove forests (46 species), offshore islands ( 23 species), and outer sea and sandbanks (14 species). According to IUCN Red List criteria, five species are characterized as near-threatened and one species, the Western Crowned-pigeon (Goura cristata) (Figure 2a), is 
listed as vulnerable. The Red Bird-of-paradise (Paradisaea rubra) (Figure 2c) was the only observed species endemic to the Raja Ampat archipelago.

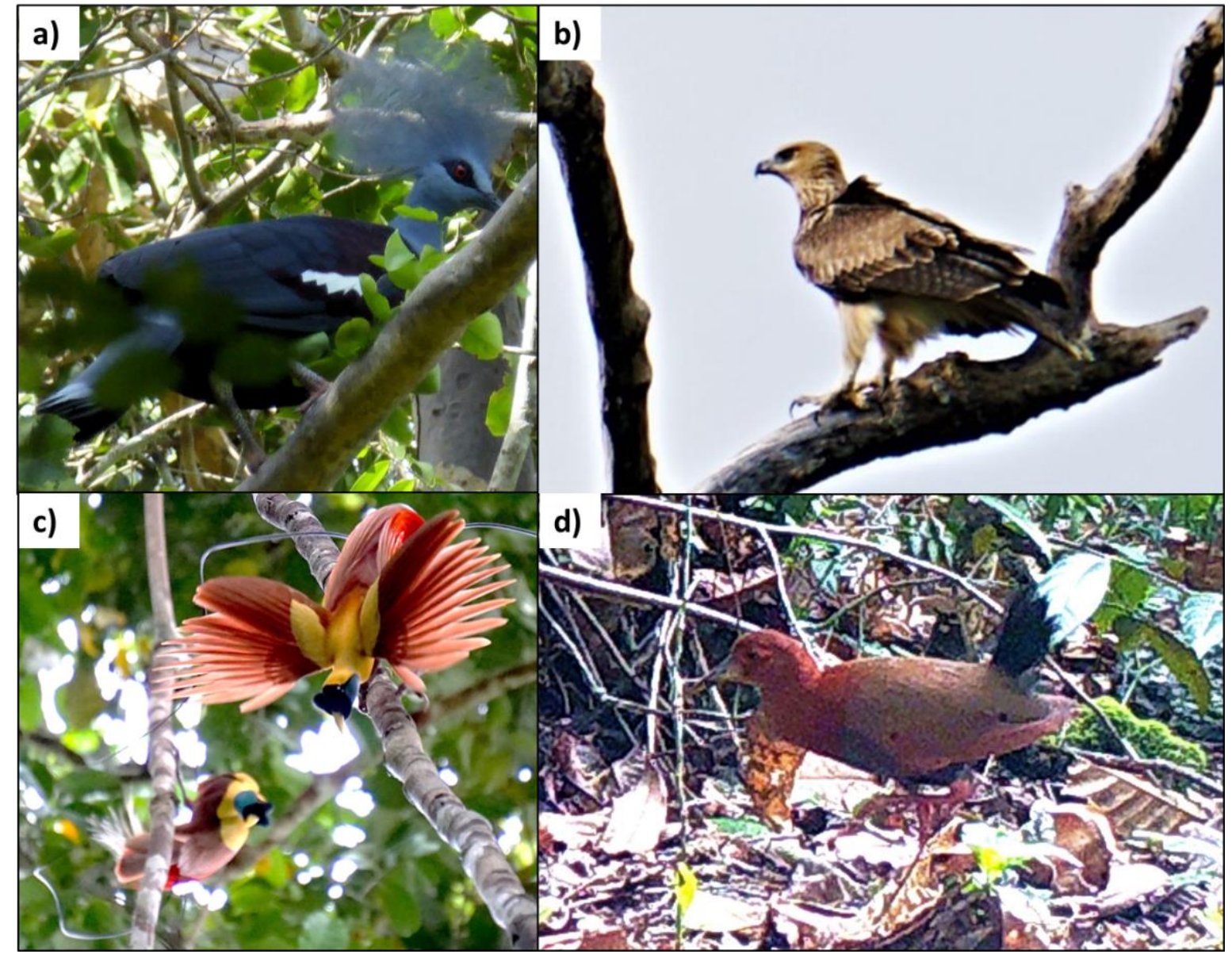

Figure 2. Noteworthy species records for Gam Island, Raja Ampat. a) The vulnerable Western Crowned-pigeon (Goura cristata) is still relatively common on Gam but possibly threatened by hunting. b) A pair with two subadults of the near-threatened Gurney's Eagle (Aquila gurneyi) were observed on Gam Island. c) The near-threatened Red Bird-ofparadise (Paradisaea rubra) is a common resident in the lowland forests of Gam. d) The Bared-eyed Rail (Gymnocrex plumbeiventris) was previously only known from mainland New Guinea and possibly from the island of Batanta. (Photo credit: (a) M. Mühlenberg; (bd) J. Schrader).

We recorded three new species occurrences for Gam Island that have neither previously been recorded in the field guides of Pratt \& Beehler (2015) and Gregory (2017), nor in any of the major online databases (see Appendix Table A2). These new records are the Black Fantail (Rhipidura atra), the Boyer's Cuckooshrike (Coracina boyeri), and the Bare-eyed Rail (Gymnocrex plumbeiventris). The first two species were previously recorded on the neighboring island of Waigeo, while the recorded Bare-eyed Rail (Figure 2d) represents the first account for central Raja Ampat with its closest records located on mainland New Guinea and possibly Batanta.

\section{Discussion}

We detected 132 bird species for the study region, while BirdLife International lists the occurrence of 70 additional species (Appendix Table A2). This large additional number of species recorded by other sources that were not recorded in our checklist might be partly rooted in the fact 
that the extent of occurrence range maps of BirdLife International are, to a certain degree, guided by expert opinion. The strong discrepancy between extent of occurrence maps and the number of detected species emphasizes the need for continuous monitoring efforts in the forests of Gam Island. Which of these species actually occur on Gam, should be verified by future surveys.

In contrast, the large neighboring island of Waigeo has 238 recorded bird species according to eBird checklists, while the extent of occurrence range maps of BirdLife International list 201 species for the island. Waigeo has received much more attention than Gam, as eBird checklists are abundant here, whereas we are only aware of one checklist for Gam Island from eBird and of one checklist that was included in a travel report by Virtue and Anyon-Smith (2014; retrieved from www.mammalwatching.com). Gam Island also supports a relatively high species richness compared to the island of Gag, for which Johnstone (2006) recorded 70 bird species during one survey trip in 1997. Gag Island is located approximately $50 \mathrm{~km}$ to the west of Gam Island. However, its oceanic nature likely acts as a dispersal filter for many species, resulting in a relatively low bird species richness. The relatively high species richness of Gam Island compared to Gag may also largely be driven by Gam's close proximity to the large and biodiverse island of Waigeo. Also, the high coverage of intact rainforests, large mangrove areas, and the numerous small islands surrounding Gam Island affect its species richness.

We found that many species on Gam Island were restricted to specific habitat types, and only a few species are considered threatened according to IUCN Red List criteria. However, many of the species were only encountered on a few occasions. We observed increased tourism activity in Raja Ampat, which suggests that the disturbance level in the forests of Gam Island is growing. The associated increased demand for construction materials and frequent birdwatching tours put rising pressure on natural resources and biodiversity of the island. We encouraged community-based conservation measures and self-regulation mechanisms during our fieldwork on Gam Island. However, to which extent these measures prove to be successful for conservation should be monitored in the future.

\subsection{Species and habitat types}

The grouping of species into specific habitat types provides detailed insights into community compositions and species ecology. Among all selected habitat types, secondary growth and villages supported the highest species richness (together with intact forests), which is probably a result of high landscape heterogeneity including villages, coconut plantations and gardens, secondary growth, and fallow land. Furthermore, we observed many species from lowland and mangrove forests passing through or foraging in the anthropogenically modified habitats. However, most species recorded in secondary growth forests are relatively common (recorded during most time periods) throughout New Guinea, and the need for conservation actions for these species to date has been relatively small.

Lowland forests also exhibited very high species richness, with $19 \%$ of the species restricted to this habitat. Also, four out of the six threatened species occurred in lowland forests. These were Gurney's Eagle (Aquila gurneyi), Red Bird-of-paradise, Brown-headed Crow (Corvus fuscicapillus), and Western Crowned-pigeon (Figure 2a-c). It is possible that the bird species richness for the forests is even higher, as other databases list many species for Gam Island that were not recorded by us (Table A2). Indeed, we recorded many bird species only on a very few occasions, as they were rare or elusive and therefore difficult to spot.

We recorded 46 bird species in the mangrove forests, with four species exclusively found here: three species of heron and the Australian Ibis (Threskiornis moluccus), which appears to be rare within the study region (only observed once in November 2016). Other, generally common, species such as the Varied Honeyeater (Gavicalis versicolor), Torresian Crow (Corvus orru), Helmeted Friarbird (Philemon buceroides), or Beach Kingfisher (Todiramphus saurophagus) used the 
mangroves for foraging. Especially large mangrove forests surrounding Gam Island attracted numerous species. Mangroves, provide important habitats to the Green-backed Heron (Butorides striata), Great-billed Heron (Ardea sumatrana), and Rufous Night Heron (Nycticorax caledonicus), which were the most common species in these small mangrove patches.

The small islands around Gam Island form a peculiar habitat type in the region, as was already noted by Alfred R. Wallace (1869, pp. 464-465). These islands range in size from a few square meters to more than one hectare (Schrader et al. 2019a), but feature a relatively high species richness (compare also to Diamond 1974; Diamond \& Lecroy 1979). Many species occurred almost exclusively here or were most common on the small islands. Noteworthy examples are the Spice Imperial-pigeon (Ducula myristicivora), which is even considered as small-island specialist (Diamond 1974; Johnstone 2006) or the Moluccan Starling (Aplonis mysolensis) that sustained a breeding colony with approximately 25 breeding pairs on an island of 0.2 ha in Gam Bay. Further, we observed species that used the small islands as nesting sites. These included the Black-naped Tern (Sterna sumatrana), Olive-backed Sunbird (Cinnyris jugularis), Ruby-throated Myzomela (Myzomela eques), Willie Wagtail (Rhipidura leucophrys), Spice Imperial-pigeon (Ducula myristicivora), Dusky Scrubfowl (Megapodius freycinet), Large-tailed Nightjar (Caprimulgus macrurus). For night roosting, the Redflanked Lorikeet (Charmosyna placentis), Red-cheeked Parrot (Geoffroyus geoffroyi), Olive-crowned Flowerpecker (Dicaeum pectorale), Rainbow Bee-eater (Merops ornatus), Green-backed Heron, Claret-breasted Fruit-dove (Ptilinopus viridis), Beach Kingfisher (Todiramphus saurophagus) also use the small islands. These species fly off to Gam Island for daytime foraging. The small islands possibly provide an important refuge for many species, as we never detected any predatory species during our surveys. Interestingly, many of the bird species are frugivorous (species diets extracted from www.hbw.com). This is mirrored by the high richness of plants with fleshy, bird-dispersed fruits (personal observation from JS).

Some islands in the region are located offshore and are thus isolated from the islands of Gam or Waigeo by open ocean, such as Fam Islands $(22 \mathrm{~km}$ ) and Yeben Island (21 km) (Figure 1b). Here, most of the birds were regularly observed traveling between islands. Six species were only observed on these offshore islands, of which four were shorebirds such as the Whimbrel (Numenius phaeopus), Ruddy Turnstone (Arenaria interpres), and Terek Sandpiper (Xenus cinereus). Also, a pair of Peregrine Falcons (Falco peregrinus) was seen nesting on one of the small offshore islands (observed in November 2016). Other species such as the Dusky Scrubfowl (Megapodius freycinet) or Pied Imperial-pigeon (Ducula bicolor) were common on most offshore islands.

Marine habitats such as open ocean, outer reefs, and periodically submerged sandbanks provided important habitats for many seabirds. The near-threatened Streaked Shearwater (Calonectris leucomelas) (a group of approximately 20 individuals observed in December 2016) and Brown Booby (Sula leucogaster) (commonly observed individually or in small groups) were observed between Gam Island and the islands of Fam. From October to March large flocks of Red-necked Phalarope (Phalaropus lobatus) (groups of 100 to 250 were commonly observed) overwintered in the pelagic parts of the study region.

\subsection{New records for Gam Island}

We recorded three bird species for Gam Island that have not previously been listed for the region. Of these, the Bare-eyed Rail (Figure $2 \mathrm{~d}$ ) was previously undocumented for central Raja Ampat and thus for Waigeo, the largest island in Raja Ampat. Possibly, the range of the Bare-eyed Rail extends to Waigeo due to the close proximity of Gam Island and Waigeo. Furthermore, both islands were probably connected in the past (Weatherall et al. 2015). The species detections recorded during our surveys highlight the chance that future monitoring efforts might yield additional, previously undetected species occurrences in the region.

Of all targeted habitat types, the lowland forest was the only habitat in which we observed new 
species during all sampling periods. We expect that more species can be recorded in the lowland forests of Gam Island with increased monitoring efforts (see also Appendix Table A2).

\subsection{Conservation}

Among all habitat types in our study region, the lowland forests supported both the highest richness of threatened species and the highest number of species confined to a single habitat. Currently, the forests on Gam Island are not protected, and increasing tourism and demand for timber and natural building materials by locals likely degrade the forest habitats (own observations). In addition, we regularly encountered snares and traps in the forests laid out by indigenous people from the local villages that, inter alia, pose a threat to the ground-dwelling Western Crowned-pigeon and the Dusky Scrubfowl. We encouraged the local communities to limit these hunting practices as they may endanger unique and charismatic wildlife. In recent years, many tourists visited the forests on Gam Island to observe the iconic Red Bird-of-paradise. Possibly, inclusion of other bird species in these ecotourism schemes may further generate income, thereby enhancing the species' value for the local communities. However, a code of conduct for bird watching should be developed with education and support of responsible local guides to mitigate adverse effects of forest species. Community-based conservation via ecotourism activities can help conserve the species-rich forests on Gam Island. However, they also pose a threat to species that are sensitive to disturbance, such as the Red Bird-of-paradise.

Gam Island is located within the Marine Recreation Park Taman Wisata Perairan Kepulauan Raja Ampat, which is currently categorized as a protected area with sustainable use of natural resources according to IUCN standard VI. However, the terrestrial ecosystems of Gam Island are not yet included in this conservation scheme and do not have any legal protection status. We argue that broader inclusion of Raja Ampat's terrestrial ecosystems into the existing conservation scheme, combined with community engagement, could foster the long-term persistence of many iconic and rare species in the region.

\subsection{Conclusion}

Gam Island features a high bird diversity supported by large expanses of natural ecosystems. As there are still undisturbed habitats in the study region, proactive conservation measures could contribute to safeguarding them in the future. Detailed accounts of species ecology and occurrences are central to helping develop effective conservation measures. However, to date, no regular terrestrial monitoring efforts exist for the Raja Ampat archipelago, and many of the islands lack comprehensive checklists. Our checklist can be used as a baseline for future bird species monitoring and to measure conservation success.

\section{Acknowledgements}

We thank Paulus Sawyai and the village of Sawinggrai for assistance in the field. Funding was provided by the DAAD with funds from the Federal Ministry for Economic Cooperation and Development (BMZ; Project no. 57142690, 57449230, 57445626) to JS, CP, MM, SM, JDK, and C. Sattler, by the Unibund Göttingen to JS, $\mathrm{CP}, \mathrm{TH}, \mathrm{CW}, \mathrm{C}$. Stinn, FM, and MM, and by the Studienstiftung des deutschen Volkes to JS and CP.

\section{Author contribution}

J.S conceived the idea; all authors recorded the bird species occurrences; J.S and C.P wrote the paper with major contribution from C. Stinn, C. Sattler, J.D.K, and S.M. All authors gave final approval for publication.

\section{Conflicts of Interest}

The authors declare no conflict of interest. 


\section{Appendix: An annotated bird checklist for Gam island, Raja Ampat, including field notes on species monitoring and conservation}

Table A1. Bird species checklist for Gam Island and adjacent regions. Species are grouped into their respective habitat types and sorted alphabetically according to family and species name. SG/V: secondary growth forest and villages; F: rainforest; M: mangrove forest; SI: surrounding small islands; OI: offshore islands; O/R: open ocean and outer reefs. Stat.: conservation status according to the IUCN Red List (2019). Numbers indicate how often each species was recorded in each habitat type over the nine sampling time frames.

\begin{tabular}{|c|c|c|c|c|c|c|c|c|c|c|c|c|}
\hline Order & Family & Species & Common name & SG/V & $\mathbf{F}$ & M & SI & ol & O/R & $\begin{array}{l}\text { No. } \\
\text { Habitats }\end{array}$ & Stat. & Comment \\
\hline \multirow[t]{3}{*}{ Anseriformes } & Anatidae & $\begin{array}{l}\text { Radjah } \\
\text { radjah }\end{array}$ & Radjah Shelduck & 6 & - & 8 & - & - & - & 2 & LC & \\
\hline & \multirow[t]{2}{*}{ Apodinae } & $\begin{array}{l}\text { Aerodramus } \\
\text { vanikorensis }\end{array}$ & Uniform Swiftlet & 9 & - & - & - & - & - & 1 & $\mathrm{LC}$ & \\
\hline & & $\begin{array}{l}\text { Collocalia } \\
\text { esculenta }\end{array}$ & Glossy Swiftlet & 9 & 9 & 9 & 9 & - & - & 4 & $\mathrm{LC}$ & $\begin{array}{l}\text { Nesting in caves } \\
\text { on Gam Island }\end{array}$ \\
\hline Galliformes & Megapodiidae & $\begin{array}{l}\text { Megapodius } \\
\text { freycinet }\end{array}$ & Dusky Scrubfowl & 9 & 9 & - & 1 & 3 & - & 4 & LC & $\begin{array}{l}\text { Nesting in forest } \\
\text { and offshore } \\
\text { islands }\end{array}$ \\
\hline \multirow[t]{11}{*}{ Columbiformes } & \multirow[t]{11}{*}{ Columbidae } & $\begin{array}{l}\text { Chalcophaps } \\
\text { stephani }\end{array}$ & $\begin{array}{l}\text { Stephan's Emerald } \\
\text { Dove }\end{array}$ & 1 & 2 & - & - & - & - & 2 & LC & \\
\hline & & $\begin{array}{l}\text { Columba } \\
\text { vitiensis }\end{array}$ & Metallic Pigeon & 1 & 2 & - & - & - & - & 2 & LC & \\
\hline & & $\begin{array}{l}\text { Ducula } \\
\text { bicolor }\end{array}$ & $\begin{array}{l}\text { Pied Imperial- } \\
\text { pigeon }\end{array}$ & - & - & - & - & 4 & - & 1 & $\mathrm{LC}$ & $\begin{array}{l}\text { Nesting on } \\
\text { offshore islands }\end{array}$ \\
\hline & & $\begin{array}{l}\text { Ducula } \\
\text { myristicivora }\end{array}$ & $\begin{array}{l}\text { Spice Imperial- } \\
\text { pigeon }\end{array}$ & - & - & 3 & 9 & - & - & 2 & LC & $\begin{array}{l}\text { Nesting on } \\
\text { small islands }\end{array}$ \\
\hline & & $\begin{array}{l}\text { Ducula } \\
\text { pinon }\end{array}$ & $\begin{array}{l}\text { Pinon Imperial- } \\
\text { pigeon }\end{array}$ & 9 & 9 & - & - & - & - & 2 & LC & \\
\hline & & $\begin{array}{l}\text { Goura } \\
\text { cristata }\end{array}$ & $\begin{array}{l}\text { Western Crowned- } \\
\text { pigeon }\end{array}$ & - & 4 & 1 & - & - & - & 2 & VU & \\
\hline & & $\begin{array}{l}\text { Macropygia } \\
\text { amboinensis }\end{array}$ & $\begin{array}{l}\text { Slender-billed } \\
\text { Cuckoo-dove }\end{array}$ & - & - & - & 2 & - & - & 1 & $\mathrm{LC}$ & \\
\hline & & $\begin{array}{l}\text { Megaloprepia } \\
\text { magnifica }\end{array}$ & $\begin{array}{l}\text { Wompoo Fruit- } \\
\text { dove }\end{array}$ & - & 2 & - & - & - & - & 1 & $\mathrm{LC}$ & \\
\hline & & $\begin{array}{l}\text { Ptilinopus } \\
\text { iozonus }\end{array}$ & $\begin{array}{l}\text { Orange-bellied } \\
\text { Fruit-dove }\end{array}$ & - & 2 & - & - & - & - & 1 & LC & \\
\hline & & $\begin{array}{l}\text { Ptilinopus } \\
\text { nainus }\end{array}$ & Dwarf Fruit-dove & 1 & - & - & - & - & - & 1 & LC & \\
\hline & & $\begin{array}{l}\text { Ptilinopus } \\
\text { perlatus }\end{array}$ & $\begin{array}{l}\text { Pink-spotted Fruit- } \\
\text { dove }\end{array}$ & - & 1 & 2 & 1 & - & - & 3 & LC & \\
\hline
\end{tabular}




\begin{tabular}{|c|c|c|c|c|c|c|c|c|c|c|c|c|}
\hline & & $\begin{array}{l}\text { Ptilinopus } \\
\text { pulchellus }\end{array}$ & $\begin{array}{l}\text { Beautiful Fruit- } \\
\text { dove }\end{array}$ & 2 & - & - & - & - & - & 1 & LC & \\
\hline & & $\begin{array}{l}\text { Ptilinopus } \\
\text { rivoli }\end{array}$ & $\begin{array}{l}\text { White-bibbed } \\
\text { Fruit-dove }\end{array}$ & - & 2 & - & - & - & - & 1 & LC & \\
\hline & & $\begin{array}{l}\text { Ptilinopus } \\
\text { superbus }\end{array}$ & Superb Fruit-dove & - & 1 & - & - & - & - & 1 & LC & \\
\hline & & $\begin{array}{l}\text { Ptilinopus } \\
\text { viridis }\end{array}$ & $\begin{array}{l}\text { Claret-breasted } \\
\text { Fruit-dove }\end{array}$ & 2 & 4 & 4 & 3 & - & - & 4 & LC & \\
\hline & & $\begin{array}{l}\text { Reinwardtoena } \\
\text { reinwardti }\end{array}$ & Great Cuckoo-dove & - & 3 & - & 2 & - & - & 2 & LC & \\
\hline \multirow[t]{2}{*}{ Cuculiformes } & \multirow[t]{2}{*}{ Cuculidae } & $\begin{array}{l}\text { Chalcites } \\
\text { minutillus }\end{array}$ & $\begin{array}{l}\text { Little Bronze- } \\
\text { cuckoo }\end{array}$ & 1 & - & 2 & - & - & - & 2 & LC & \\
\hline & & $\begin{array}{l}\text { Scythrops } \\
\text { novaehollandiae }\end{array}$ & $\begin{array}{l}\text { Channel-billed } \\
\text { Cuckoo }\end{array}$ & - & 1 & - & - & - & - & 1 & LC & \\
\hline \multirow[t]{3}{*}{ Caprimulgiformes } & Podargidae & $\begin{array}{l}\text { Podargus } \\
\text { papuensis }\end{array}$ & Papuan Frogmouth & - & 3 & - & - & - & - & 1 & LC & \\
\hline & Caprimulgidae & $\begin{array}{l}\text { Caprimulgus } \\
\text { macrurus }\end{array}$ & $\begin{array}{l}\text { Large-tailed } \\
\text { Nightjar }\end{array}$ & 2 & - & - & 1 & - & - & 2 & LC & $\begin{array}{l}\text { Nesting on } \\
\text { small islands }\end{array}$ \\
\hline & Hemiprocnidae & $\begin{array}{l}\text { Hemiprocne } \\
\text { mystacea }\end{array}$ & $\begin{array}{l}\text { Moustached } \\
\text { Treeswift }\end{array}$ & 7 & 9 & 6 & 4 & - & - & 4 & LC & \\
\hline \multirow[t]{2}{*}{ Gruiformes } & \multirow[t]{2}{*}{ Rallidae } & $\begin{array}{l}\text { Gymnocrex } \\
\text { plumbeiventris }\end{array}$ & Bare-eyed rail & - & 1 & - & - & - & - & 1 & LC & $\begin{array}{l}\text { Observed with } \\
\text { chicks }\end{array}$ \\
\hline & & Rallina tricolor & Red-necked Crake & - & 1 & - & - & - & - & 1 & LC & \\
\hline \multirow[t]{9}{*}{ Charadriiformes } & Burhinidae & $\begin{array}{l}\text { Esacus } \\
\text { magnirostris }\end{array}$ & Beach Thick-knee & - & - & - & - & 1 & - & 1 & NT & \\
\hline & \multirow[t]{5}{*}{ Scolopacidae } & $\begin{array}{l}\text { Actitis } \\
\text { hypoleucos }\end{array}$ & $\begin{array}{l}\text { Common } \\
\text { Sandpiper }\end{array}$ & - & - & 5 & 7 & - & - & 2 & LC & \\
\hline & & $\begin{array}{l}\text { Arenaria } \\
\text { interpres }\end{array}$ & Ruddy Turnstone & - & - & - & - & 1 & - & 1 & LC & \\
\hline & & $\begin{array}{l}\text { Numenius } \\
\text { phaeopus }\end{array}$ & Whimbrel & - & - & - & - & 2 & - & 1 & LC & \\
\hline & & $\begin{array}{l}\text { Phalaropus } \\
\text { lobatus }\end{array}$ & $\begin{array}{l}\text { Red-necked } \\
\text { Phalarope }\end{array}$ & - & - & - & - & - & 5 & 1 & LC & \\
\hline & & Xenus cinereus & Terek Sandpiper & - & - & - & - & 1 & - & 1 & LC & \\
\hline & \multirow[t]{3}{*}{ Laridae } & Anous minutus & Black Noddy & - & - & - & 1 & - & - & 1 & LC & \\
\hline & & $\begin{array}{l}\text { Onychoprion } \\
\text { anaethetus }\end{array}$ & Bridled Tern & - & - & - & 4 & 9 & 9 & 3 & LC & \\
\hline & & $\begin{array}{l}\text { Onychoprion } \\
\text { fuscatus }\end{array}$ & Sooty Tern & - & - & - & - & - & 9 & 1 & LC & \\
\hline
\end{tabular}




\begin{tabular}{|c|c|c|c|c|c|c|c|c|c|c|c|c|}
\hline & & Sterna hirundo & Common Tern & - & - & - & 1 & - & 3 & 2 & LC & \\
\hline & & $\begin{array}{l}\text { Sterna } \\
\text { sumatrana }\end{array}$ & Black-naped Tern & - & - & - & 5 & 3 & 3 & 3 & LC & $\begin{array}{l}\text { Nesting on } \\
\text { small islands }\end{array}$ \\
\hline & & $\begin{array}{l}\text { Sternula } \\
\text { albifrons }\end{array}$ & Little Tern & - & - & - & - & 1 & 2 & 2 & LC & \\
\hline & & $\begin{array}{l}\text { Thalasseus } \\
\text { bengalensis }\end{array}$ & Lesser Crested Tern & - & - & - & - & - & 1 & 1 & LC & \\
\hline & & Thalasseus bergii & Great Crested Tern & - & - & - & 1 & 3 & 5 & 3 & LC & \\
\hline Procellariiformes & Procellariidae & $\begin{array}{l}\text { Calonectris } \\
\text { leucomelas }\end{array}$ & $\begin{array}{l}\text { Streaked } \\
\text { Shearwater }\end{array}$ & - & - & - & - & - & 2 & 1 & NT & \\
\hline \multirow[t]{5}{*}{ Suliformes } & \multirow[t]{2}{*}{ Fregatidae } & Fregata ariel & Lesser Frigatebird & - & - & - & 9 & 9 & 9 & 3 & LC & \\
\hline & & Fregata minor & Great Frigatebird & - & - & - & - & - & 4 & 1 & LC & \\
\hline & Sulidae & Sula leucogaster & Brown Booby & - & - & - & - & - & 4 & 1 & LC & \\
\hline & \multirow[t]{2}{*}{ Phalacrocoracidae } & $\begin{array}{l}\text { Microcarbo } \\
\text { melanoleucos }\end{array}$ & $\begin{array}{l}\text { Little Pied } \\
\text { Cormorant }\end{array}$ & - & - & 6 & - & - & - & 1 & LC & \\
\hline & & Ardea alba & Great White Egret & & & & 1 & & & 1 & LC & \\
\hline \multirow[t]{7}{*}{ Pelecaniformes } & \multirow[t]{6}{*}{ Ardeidae } & $\begin{array}{l}\text { Ardea } \\
\text { intermedia }\end{array}$ & Intermediate Egret & - & - & 4 & - & - & - & 1 & LC & \\
\hline & & $\begin{array}{l}\text { Ardea } \\
\text { sumatrana }\end{array}$ & Great-billed Heron & - & 3 & 6 & 9 & - & - & 3 & LC & \\
\hline & & $\begin{array}{l}\text { Butorides } \\
\text { striata }\end{array}$ & $\begin{array}{l}\text { Green-backed } \\
\text { Heron }\end{array}$ & - & - & 9 & 9 & 4 & - & 3 & LC & \\
\hline & & $\begin{array}{l}\text { Egretta } \\
\text { sacra }\end{array}$ & Pacific Reef-egret & 7 & - & 9 & 9 & 9 & 9 & 5 & LC & \\
\hline & & $\begin{array}{l}\text { Ixobrychus } \\
\text { flavicollis }\end{array}$ & Black Bittern & - & - & 3 & - & - & - & 1 & LC & \\
\hline & & $\begin{array}{l}\text { Nycticorax } \\
\text { caledonicus }\end{array}$ & Rufous Night-heron & 3 & - & 5 & 2 & - & - & 3 & LC & \\
\hline & Threskiornithidae & $\begin{array}{l}\text { Threskiornis } \\
\text { moluccus }\end{array}$ & Australian Ibis & - & - & 1 & - & - & - & 1 & LC & \\
\hline Accipitriformes & Pandionidae & $\begin{array}{l}\text { Pandion } \\
\text { haliaetus }\end{array}$ & Osprey & 7 & - & 6 & 7 & 4 & 2 & 5 & $\mathrm{LC}$ & \\
\hline Bucerotiformes & Bucerotidae & $\begin{array}{l}\text { Rhyticeros } \\
\text { plicatus }\end{array}$ & Blyth's Hornbill & 9 & 9 & - & - & - & - & 2 & $\mathrm{LC}$ & \\
\hline \multirow[t]{2}{*}{ Coraciiformes } & Meropidae & $\begin{array}{l}\text { Merops } \\
\text { ornatus }\end{array}$ & Rainbow Bee-Eater & 5 & - & - & 6 & 3 & - & 3 & LC & \\
\hline & Coraciidae & $\begin{array}{l}\text { Eurystomus } \\
\text { orientalis }\end{array}$ & Oriental Dollarbird & 6 & - & 3 & 4 & - & - & 3 & $\mathrm{LC}$ & \\
\hline
\end{tabular}




\begin{tabular}{|c|c|c|c|c|c|c|c|c|c|c|c|c|}
\hline Falconiformes & Falconidae & $\begin{array}{l}\text { Falco } \\
\text { peregrinus }\end{array}$ & Peregrine Falcon & - & - & - & - & 1 & - & 1 & LC & $\begin{array}{l}\text { Nesting on } \\
\text { offshore islands }\end{array}$ \\
\hline \multirow[t]{11}{*}{ Psittaciformes } & \multirow[t]{2}{*}{ Cacatuidae } & $\begin{array}{l}\text { Cacatua } \\
\text { galerita }\end{array}$ & $\begin{array}{l}\text { Sulphur-crested } \\
\text { Cockatoo }\end{array}$ & 9 & 9 & 5 & 6 & - & - & 4 & LC & $\begin{array}{l}\text { Nesting in } \\
\text { forest }\end{array}$ \\
\hline & & $\begin{array}{l}\text { Probosciger } \\
\text { aterrimus }\end{array}$ & Palm Cockatoo & 7 & 5 & 6 & 4 & - & - & 4 & LC & \\
\hline & \multirow[t]{9}{*}{ Psittacidae } & $\begin{array}{l}\text { Alisterus } \\
\text { amboinensis }\end{array}$ & $\begin{array}{l}\text { Moluccan King- } \\
\text { parrot }\end{array}$ & - & 2 & - & - & - & - & 1 & LC & \\
\hline & & $\begin{array}{l}\text { Charmosyna } \\
\text { placentis }\end{array}$ & $\begin{array}{l}\text { Red-flanked } \\
\text { Lorikeet }\end{array}$ & - & - & - & 2 & - & - & 1 & LC & \\
\hline & & Eclectus roratus & Eclectus Parrot & 9 & 9 & - & 6 & - & - & 3 & LC & $\begin{array}{l}\text { Nesting in } \\
\text { forest }\end{array}$ \\
\hline & & Eos squamata & Violet-necked Lory & 9 & 3 & 6 & 5 & 2 & - & 5 & LC & \\
\hline & & $\begin{array}{l}\text { Geoffroyus } \\
\text { geoffroyi }\end{array}$ & $\begin{array}{l}\text { Red-cheeked } \\
\text { Parrot }\end{array}$ & 9 & 9 & 9 & 9 & - & - & 4 & LC & \\
\hline & & $\begin{array}{l}\text { Loriculus } \\
\text { aurantiifrons }\end{array}$ & $\begin{array}{l}\text { Orange-fronted } \\
\text { Hanging-parrot }\end{array}$ & 1 & - & - & - & - & - & 1 & LC & \\
\hline & & Lorius lory & Black-capped Lory & 2 & - & - & - & - & - & 1 & LC & \\
\hline & & $\begin{array}{l}\text { Tanygnathus } \\
\text { megalorynchos }\end{array}$ & Great-billed Parrot & 2 & - & - & 4 & - & - & 2 & LC & \\
\hline & & $\begin{array}{l}\text { Trichoglossus } \\
\text { haematodus }\end{array}$ & Rainbow Lorikeet & 1 & 2 & - & 2 & - & - & 3 & LC & \\
\hline \multirow[t]{10}{*}{ Passeriformes } & \multirow[t]{5}{*}{ Accipitridae } & $\begin{array}{l}\text { Accipiter } \\
\text { hiogaster }\end{array}$ & Variable Goshawk & 2 & - & - & - & - & - & 1 & LC & \\
\hline & & $\begin{array}{l}\text { Accipiter } \\
\text { poliocephalus }\end{array}$ & $\begin{array}{l}\text { Grey-headed } \\
\text { Goshawk }\end{array}$ & 3 & - & - & - & - & - & 1 & LC & \\
\hline & & Aquila gurneyi & Gurney's Eagle & 2 & 2 & 2 & - & - & - & 3 & NT & \\
\hline & & $\begin{array}{l}\text { Haliaeetus } \\
\text { leucogaster }\end{array}$ & $\begin{array}{l}\text { White-bellied Sea- } \\
\text { eagle }\end{array}$ & 9 & - & - & 9 & 6 & - & 3 & LC & \\
\hline & & Haliastur indus & Brahminy Kite & 9 & 7 & 7 & 5 & - & - & 4 & LC & \\
\hline & \multirow[t]{5}{*}{ Alcedinidae } & Ceyx azureus & Azure Kingfisher & - & 1 & 4 & - & - & - & 2 & $\mathrm{LC}$ & \\
\hline & & Ceyx pusillus & Little Kingfisher & 1 & - & - & - & - & - & 1 & LC & \\
\hline & & $\begin{array}{l}\text { Dacelo } \\
\text { gaudichaud }\end{array}$ & $\begin{array}{l}\text { Rufous-bellied } \\
\text { Kookaburra }\end{array}$ & 1 & 2 & 4 & 5 & - & - & 4 & $\mathrm{LC}$ & \\
\hline & & Syma torotoro & $\begin{array}{l}\text { Yellow-billed } \\
\text { Kingfisher }\end{array}$ & 1 & 6 & - & 2 & - & - & 3 & LC & \\
\hline & & $\begin{array}{l}\text { Tanysiptera } \\
\text { galatea }\end{array}$ & $\begin{array}{l}\text { Common Paradise- } \\
\text { kingfisher }\end{array}$ & - & 5 & - & - & - & - & 1 & LC & \\
\hline
\end{tabular}




\begin{tabular}{|c|c|c|c|c|c|c|c|c|c|c|c|}
\hline & $\begin{array}{l}\text { Todiramphus } \\
\text { sanctus }\end{array}$ & Sacred Kingfisher & - & 1 & 1 & - & - & - & 2 & LC & \\
\hline & $\begin{array}{l}\text { Todiramphus } \\
\text { saurophagus }\end{array}$ & Beach Kingfisher & 9 & - & 9 & 9 & - & - & 3 & LC & $\begin{array}{l}\text { Nesting in } \\
\text { coconut trees } \\
\text { in termite nest }\end{array}$ \\
\hline Pittidae & $\begin{array}{l}\text { Pitta } \\
\text { novaeguineae }\end{array}$ & $\begin{array}{l}\text { Eastern Hooded } \\
\text { Pitta }\end{array}$ & 1 & 1 & - & - & - & - & 2 & LC & \\
\hline \multirow[t]{8}{*}{ Meliphagidae } & $\begin{array}{l}\text { Gavicalis } \\
\text { versicolor }\end{array}$ & Varied Honeyeater & 9 & - & 9 & 6 & 4 & - & 4 & LC & \\
\hline & $\begin{array}{l}\text { Melilestes } \\
\text { megarhynchus }\end{array}$ & $\begin{array}{l}\text { Long-billed } \\
\text { Honeyeater }\end{array}$ & 7 & 5 & - & - & - & - & 2 & LC & $\begin{array}{l}\text { Nesting in } \\
\text { secondary } \\
\text { growth }\end{array}$ \\
\hline & $\begin{array}{l}\text { Microptilotis } \\
\text { analogus }\end{array}$ & Mimic Honeyeater & 9 & 5 & 7 & - & - & - & 3 & LC & \\
\hline & $\begin{array}{l}\text { Myzomela } \\
\text { eques }\end{array}$ & $\begin{array}{l}\text { Ruby-throated } \\
\text { Myzomela }\end{array}$ & 4 & 2 & 3 & 1 & - & - & 4 & LC & \\
\hline & $\begin{array}{l}\text { Myzomela } \\
\text { nigrita }\end{array}$ & $\begin{array}{l}\text { Papuan Black } \\
\text { Myzomela }\end{array}$ & - & 1 & - & - & - & - & 1 & LC & \\
\hline & $\begin{array}{l}\text { Philemon } \\
\text { buceroides }\end{array}$ & Helmeted Friarbird & 9 & 9 & 9 & 9 & - & - & 4 & LC & \\
\hline & $\begin{array}{l}\text { Xanthotis } \\
\text { flaviventer }\end{array}$ & $\begin{array}{l}\text { Tawny-breasted } \\
\text { Honeyeater }\end{array}$ & 1 & 4 & - & - & - & - & 2 & LC & \\
\hline & $\begin{array}{l}\text { Xanthotis } \\
\text { polygrammus }\end{array}$ & $\begin{array}{l}\text { Spotted } \\
\text { Honeyeater }\end{array}$ & 2 & - & 4 & - & - & - & 2 & LC & \\
\hline \multirow[t]{2}{*}{ Acanthizidae } & $\begin{array}{l}\text { Crateroscelis } \\
\text { murina }\end{array}$ & $\begin{array}{l}\text { Rusty Mouse- } \\
\text { warbler }\end{array}$ & 1 & 3 & - & - & - & - & 2 & LC & \\
\hline & $\begin{array}{l}\text { Gerygone } \\
\text { magnirostris }\end{array}$ & $\begin{array}{l}\text { Large-billed } \\
\text { Gerygone }\end{array}$ & 3 & - & 2 & - & - & - & 2 & LC & \\
\hline \multirow[t]{4}{*}{ Campephagidae } & Coracina boyeri & $\begin{array}{l}\text { Barred } \\
\text { Cuckooshrike }\end{array}$ & 1 & - & 1 & - & - & - & 2 & LC & \\
\hline & $\begin{array}{l}\text { Coracina } \\
\text { papuensis }\end{array}$ & $\begin{array}{l}\text { White-bellied } \\
\text { Cuckoo-shrike }\end{array}$ & 2 & - & 3 & 1 & - & - & 3 & LC & \\
\hline & $\begin{array}{l}\text { Edolisoma } \\
\text { incertum }\end{array}$ & $\begin{array}{l}\text { Black-shouldered } \\
\text { Cicadabird }\end{array}$ & - & 1 & - & - & - & - & 1 & LC & \\
\hline & $\begin{array}{l}\text { Edolisoma } \\
\text { melas }\end{array}$ & Black Cicadabird & - & 1 & - & 1 & 1 & - & 3 & LC & \\
\hline \multirow[t]{2}{*}{ Pachycephalidae } & $\begin{array}{l}\text { Colluricincla } \\
\text { megarhyncha }\end{array}$ & Little Shrike-thrush & - & 2 & - & - & - & - & 1 & LC & \\
\hline & $\begin{array}{l}\text { Pseudorectes } \\
\text { ferrugineus }\end{array}$ & Rusty Pitohui & - & 3 & - & - & - & - & 1 & LC & \\
\hline Oriolidae & Oriolus szalayi & Brown Oriole & - & 2 & - & - & - & - & 1 & $\mathrm{LC}$ & \\
\hline
\end{tabular}




\begin{tabular}{|c|c|c|c|c|c|c|c|c|c|c|c|}
\hline Machaerirhynchidae & $\begin{array}{l}\text { Machaerirhynchus } \\
\text { flaviventer }\end{array}$ & $\begin{array}{l}\text { Yellow-Breasted } \\
\text { Boatbill }\end{array}$ & & 1 & - & - & - & - & 1 & LC & \\
\hline \multirow[t]{3}{*}{ Artamidae } & $\begin{array}{l}\text { Artamus } \\
\text { leucorynchus }\end{array}$ & $\begin{array}{l}\text { White-breasted } \\
\text { Woodswallow }\end{array}$ & 9 & 9 & 5 & 9 & - & - & 4 & LC & \\
\hline & Cracticus cassicus & $\begin{array}{l}\text { Hooded } \\
\text { Butcherbird }\end{array}$ & 9 & 6 & 7 & 5 & - & - & 4 & LC & \\
\hline & Melloria quoyi & Black Butcherbird & - & 2 & 4 & - & - & - & 2 & $\mathrm{LC}$ & \\
\hline \multirow[t]{3}{*}{ Rhipiduridae } & Rhipidura atra & Black Fantail & - & 1 & - & - & - & - & 1 & LC & \\
\hline & Rhipidura isura & Northern Fantail & 3 & 5 & - & - & - & - & 2 & LC & \\
\hline & $\begin{array}{l}\text { Rhipidura } \\
\text { leucophrys }\end{array}$ & Willie Wagtail & 9 & - & 9 & 9 & 7 & - & 4 & LC & $\begin{array}{l}\text { Nesting on } \\
\text { small islands } \\
\text { and village }\end{array}$ \\
\hline Dicruridae & $\begin{array}{l}\text { Dicrurus } \\
\text { bracteatus }\end{array}$ & Spangled Drongo & 2 & 7 & - & - & - & - & 2 & LC & \\
\hline \multirow[t]{2}{*}{ Paradisaeidae } & Manucodia ater & $\begin{array}{l}\text { Glossy-mantled } \\
\text { Manucode }\end{array}$ & 2 & 4 & - & 1 & - & - & 3 & LC & \\
\hline & Paradisaea rubra & $\begin{array}{l}\text { Red Bird-of- } \\
\text { paradise }\end{array}$ & - & 9 & - & - & - & - & 1 & NT & \\
\hline \multirow[t]{4}{*}{ Monarchidae } & $\begin{array}{l}\text { Arses } \\
\text { telescopthalmus }\end{array}$ & Frilled Monarch & - & 1 & - & - & - & - & 1 & LC & \\
\hline & $\begin{array}{l}\text { Monarcha } \\
\text { cinerascens }\end{array}$ & Island Monarch & - & 1 & - & - & - & - & 1 & LC & \\
\hline & Myiagra alecto & Shining Flycatcher & 2 & 4 & 2 & - & - & - & 3 & LC & \\
\hline & $\begin{array}{l}\text { Symposiachrus } \\
\text { guttula }\end{array}$ & $\begin{array}{l}\text { Spot-winged } \\
\text { Monarch }\end{array}$ & - & 3 & - & - & - & - & 1 & LC & \\
\hline \multirow[t]{2}{*}{ Corvidae } & $\begin{array}{l}\text { Corvus } \\
\text { fuscicapillus }\end{array}$ & $\begin{array}{l}\text { Brown-headed } \\
\text { Crow }\end{array}$ & - & 1 & - & - & - & - & 1 & NT & \\
\hline & Corvus orru & Torresian Crow & 9 & 9 & 9 & 7 & - & - & 4 & LC & \\
\hline \multirow[t]{4}{*}{ Melanocharitidae } & $\begin{array}{l}\text { Melanocharis } \\
\text { nigra }\end{array}$ & Black Berrypecker & - & 1 & - & - & - & - & 1 & LC & \\
\hline & $\begin{array}{l}\text { Oedistoma } \\
\text { iliolophus }\end{array}$ & Spectacled Longbill & - & 1 & - & - & - & - & 1 & LC & \\
\hline & $\begin{array}{l}\text { Oedistoma } \\
\text { pygmaeum }\end{array}$ & Pygmy Longbill & 1 & 4 & - & - & - & - & 2 & LC & \\
\hline & $\begin{array}{l}\text { Toxorhamphus } \\
\text { novaeguineae }\end{array}$ & $\begin{array}{l}\text { Yellow-bellied } \\
\text { Longbill }\end{array}$ & 2 & 5 & - & - & - & - & 2 & LC & \\
\hline \multirow[t]{2}{*}{ Hirundinidae } & Hirundo rustica & Barn Swallow & 2 & - & - & - & - & - & 1 & LC & \\
\hline & Hirundo tahitica & Pacific Swallow & 9 & - & 4 & 5 & 2 & - & 4 & LC & \\
\hline
\end{tabular}




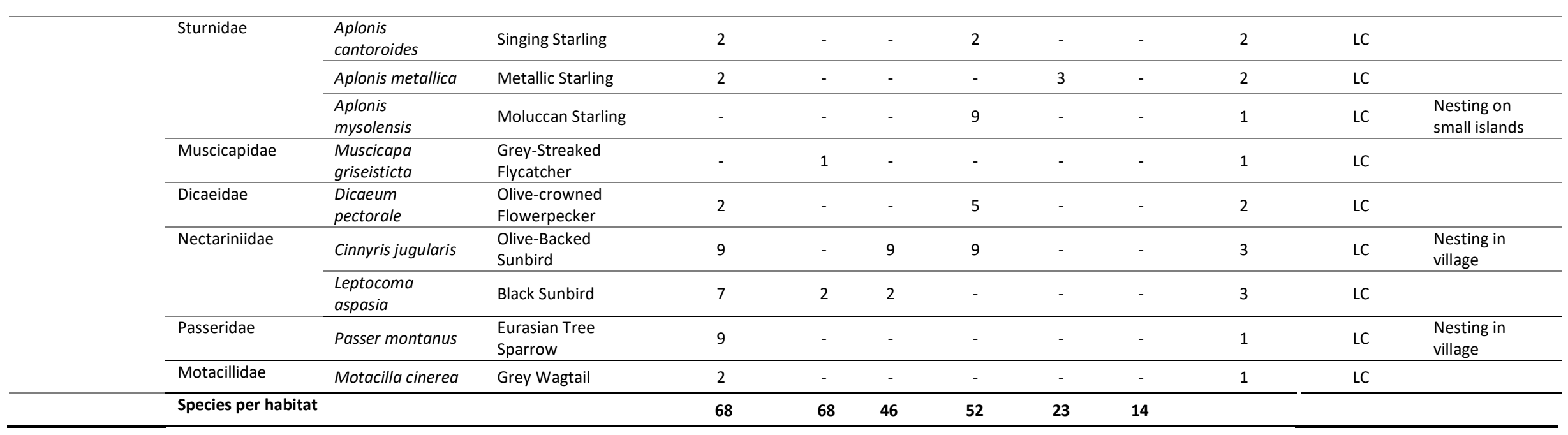


Table A2. Bird species not detected during surveys of the present work, but registered for Gam island in the databases of BirdLife International (www.birdlife.org; accessed March 2020), eBird (www.ebird.org/home; accessed March 2020), and GBIF (www.gbif.org; accessed March 2020).

\begin{tabular}{|c|c|c|c|c|c|c|}
\hline Order & Family & Species & Common name & BirdLife & eBird & GBIF \\
\hline \multirow[t]{2}{*}{ Anseriformes } & \multirow[t]{2}{*}{ Anatidae } & Anas gracilis & Grey Teal & $x$ & & \\
\hline & & Anas superciliosa & Pacific Black Duck & $x$ & & \\
\hline Galliformes & Phasianidae & Synoicus chinensis & Asian Blue Quail & $\mathrm{x}$ & & \\
\hline \multirow[t]{7}{*}{ Columbiformes } & \multirow[t]{7}{*}{ Columbidae } & Caloenas nicobarica & Nicobar Pigeon & $x$ & & \\
\hline & & Chalcophaps indica & Grey-capped Emerald Dove & $x$ & & \\
\hline & & Columba livia & Rock Dove & & & $x$ \\
\hline & & Ducula rufigaster & Purple-tailed Imperial-pigeon & $\mathrm{x}$ & & $\mathrm{x}$ \\
\hline & & Gallicolumba rufigula & Cinnamon Ground-dove & $\mathrm{x}$ & & $\mathrm{x}$ \\
\hline & & Macropygia phasianella & Brown Cuckoo-dove & & & \\
\hline & & Otidiphaps nobilis & Green-naped Pheasant-pigeon & $x$ & & \\
\hline \multirow[t]{4}{*}{ Cuculiformes } & \multirow[t]{4}{*}{ Cuculidae } & Cacomantis castaneiventris & Chestnut-breasted Cuckoo & & & $x$ \\
\hline & & Chalcites megarhynchus & Long-billed Cuckoo & $x$ & & \\
\hline & & Cuculus saturatus & Oriental Cuckoo & $\mathrm{x}$ & & \\
\hline & & Eudynamys orientalis & Eastern Koel & $\mathrm{x}$ & & \\
\hline \multirow[t]{2}{*}{ Caprimulgiformes } & Podargidae & Podargus ocellatus & Marbled Frogmouth & $\mathrm{x}$ & & \\
\hline & Apodidae & Apus pacificus & Pacific Swift & $x$ & & $x$ \\
\hline \multirow[t]{2}{*}{ Pelecaniformes } & \multirow[t]{2}{*}{ Ardeidae } & Ardea alba & Great White Egret & $\mathrm{x}$ & & \\
\hline & & Ardea plumifera & Plumed Egret & $\mathrm{x}$ & & \\
\hline \multirow[t]{10}{*}{ Charadriiformes } & \multirow[t]{4}{*}{ Charadriidae } & Charadrius leschenaultii & Greater Sandplover & $x$ & & $x$ \\
\hline & & Charadrius mongolus & Lesser Sandplover & $x$ & & $x$ \\
\hline & & Pluvialis fulva & Pacific Golden Plover & $x$ & & $\mathrm{x}$ \\
\hline & & Pluvialis squatarola & Grey Plover & $x$ & & \\
\hline & \multirow[t]{6}{*}{ Scolopacidae } & Calidris ruficollis & Red-necked Stint & $x$ & & \\
\hline & & Limosa lapponica & Bar-tailed Godwit & $x$ & & \\
\hline & & Limosa limosa & Black-tailed Godwit & $\mathrm{x}$ & & \\
\hline & & Numenius madagascariensis & Far Eastern Curlew & & $\mathrm{x}$ & $\mathrm{x}$ \\
\hline & & Tringa brevipes & Grey-tailed Tattler & $\mathrm{x}$ & & $\mathrm{x}$ \\
\hline & & Tringa glareola & Wood Sandpiper & $\mathrm{x}$ & & \\
\hline
\end{tabular}




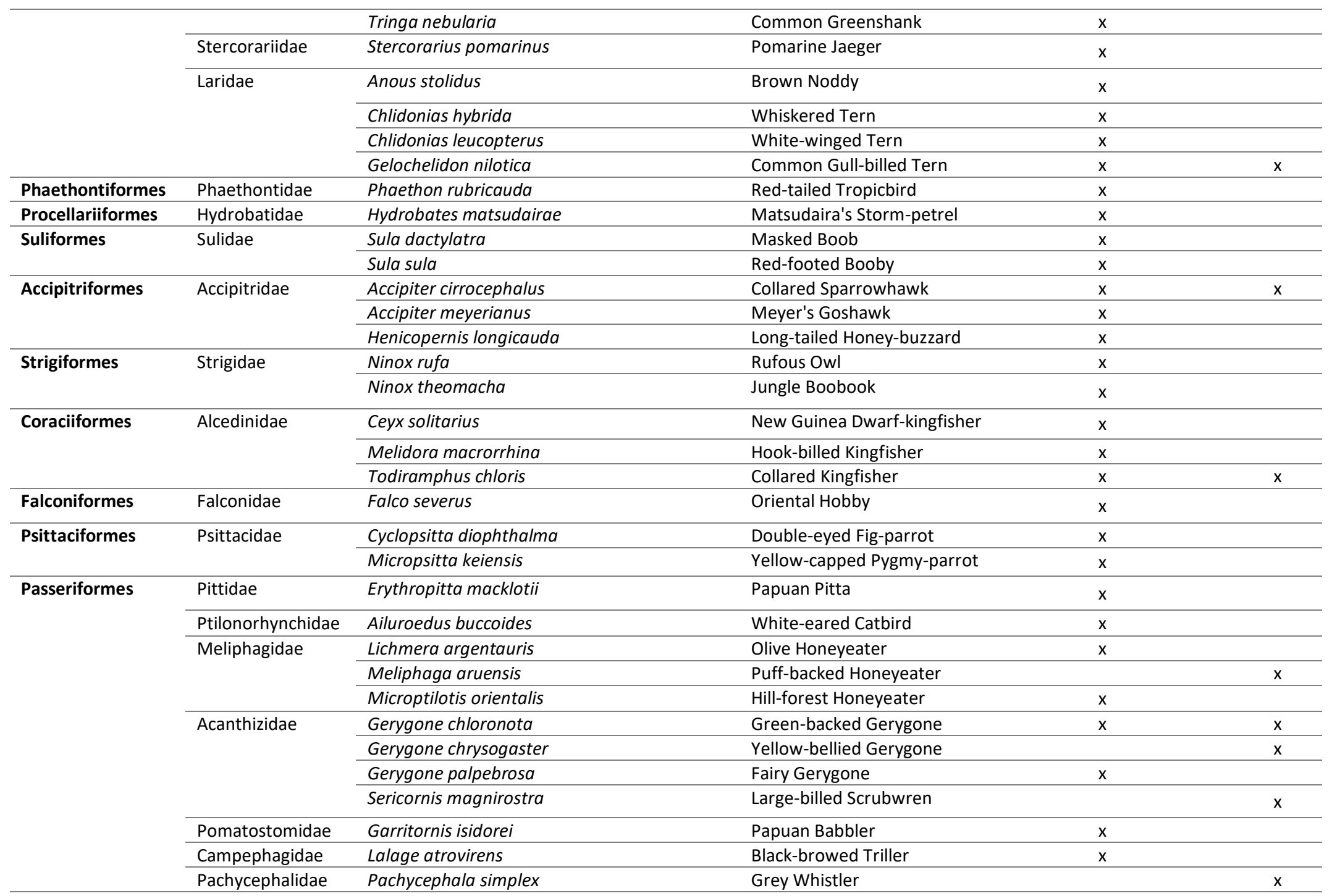




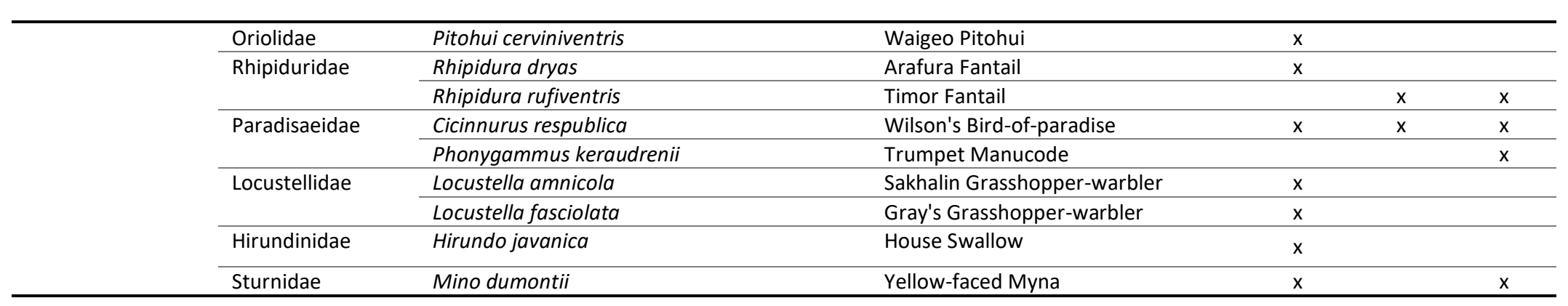




\section{References}

Allison, A. (2007). Introduction to the fauna of Papua. In: The Ecology of Papua Part One. The Ecology of Indonesia Series VI (ed. Marshall, A.J. and Beehler, B.M.). Periplus Editions, Singapore, pp. 479-494.

Beehler, B.M. (2007). Introduction to Papua. In: Ecology of Indonesian Papua Part One. The Ecology of Indonesia Series VI (eds. Marshall, A.J. \& Beehler, B.M.). Periplus Editions, Singapore.

Beehler, B.M. \& Pratt, T.K. (2016). Birds of New Guinea: distribution, taxonomy, and systematics. Princeton University Press

Cámara-Leret, R., Schuiteman, A., Utteridge, T., Bramley, G., Deverell, R., Fisher, L.A., McLeod, J., Hannah, L., Roehrdanz, P., Laman, T.G., Scholes, E., De Fretes, Y. \& Heatubun, C. (2019a). The Manokwari Declaration: Challenges ahead in conserving 70\% of Tanah Papua's forests. Forest and Society, 3, 148-151. doi: http://dx.doi.org/10.24259/fs.v3i1.6067

Cámara-Leret, R., Raes, N., Roehrdanz, P., De Fretes, Y., Heatubun, C.D., Roeble, L., Schuiteman, A., van Welzen, P.C. \& Hannah, L. (2019b). Climate change threatens New Guinea's biocultural heritage. Science Advances, 5, eaaz1455. doi: http://dx.doi.org/10.1126/sciadv.aaz1455

Diamond, J.M. \& Bishop, K. D. (2015). Avifaunas of the Kumawa and Fakfak Mountains, Indonesian New Guinea. Bulletin of the British Ornithologists' Club, 135, 292-336.

Diamond, J.M. \& Lecroy, M. (1979). Birds of Karkar and Bagabag islands, New Guinea. Bulletin American Museum of Natural History, 164, 467-531.

Diamond, J.M. (1972). Biogeographic kinetics: estimation of relaxation times for avifaunas of Southwest Pacific Islands. Proceedings of the National Academy of Sciences, 69, 3199-3203. doi: https://doi.org/10.1073/pnas.69.11.3199

Diamond, J.M. (1974). Colonization of exploded volcanic islands by birds: the supertramp strategy. Science, 184, 803-806. doi: https://doi.org/10.1126/science.184.4138.803

Djarwoto, A., Suhendar, R., Lastiadi, H.A. \& others. (2013). Geodiversity Raja Ampat islands and tourism development. International Proceedings of Chemical, Biological and Environmental Engineering (IPCBEE), 52, 10-13.

Freeman, B.G. \& Class Freeman, A.M. (2014). Rapid upslope shifts in New Guinean birds illustrate strong distributional responses of tropical montane species to global warming. Proceedings of the National Academy of Sciences of the United States of America, 111, 4490-4494. doi: https://doi.org/10.1073/pnas.1318190111

Gregory, P. (2017). Birds of New Guinea Including Bismarck Archipelago and Bougainville. Lynx Editions. Barcelona.

Heads, M. (2002). Birds of paradise, biogeography and ecology in New Guinea: A review. Journal of Biogeography, 28, 893-925. doi: https://doi.org/10.1046/j.1365-2699.2001.00600.x

IUCN. (2019). The IUCN Red List of Threatened Species [WWW Document]. Version 2019-2.

Johnstone, R.E. (2006). The birds of Gag Island, Western Papuan Islands, Indonesia. Records of the Western Australian Museum, 23, 115-132. doi: https://doi.org/10.18195/issn.03123162.23(2).2006.115-132

Kreft, H. \& Jetz, W. (2010). A framework for delineating biogeographical regions based on species distributions. Journal of Biogeography, 37, 2029-2053. doi: https://doi.org/10.1111/j.13652699.2010.02375.x

Mack, A. \& Dumbacher, J. (2007). Birds of Papua. In: The Ecology of Papua Part One. The Ecology of Indonesia Series VI (ed. Marshall, A.J. and Beehler, B.M.). Periplus Editions, Singapore, pp. 654688.

Marshall, A.J. \& Beehler, B.M. (2007). Ecology of Indonesian Papua Part Two. The Ecology of Indonesia Series VI. Periplus Editions, Singapore.

McLeod, E., Szuster, B. \& Salm, R. (2009). Sasi and Marine Conservation in Raja Ampat, Indonesia. Coastal Management, 37, 656-676. doi: https://doi.org/10.1080/08920750903244143 
Meyer, C., Kreft, H., Guralnick, R. \& Jetz, W. (2015). Global priorities for an effective information basis of biodiversity distributions. Nature Communications, 6, 8221. doi: https://doi.org/10.1038/ncomms9221

Mittermeier, R.A., Mittermeier, C.G., Brooks, T.M., Pilgrim, J.D., Konstant, W.R., da Fonseca, G.A.B. \& Kormos, C. (2003). Wilderness and biodiversity conservation. Proceedings of the National Academy of Sciences, 100, 10309. doi: https://doi.org/10.1073/pnas.1732458100

Noske, R.A., Green, B.S., Phillips, R., Laman, T.G. \& Wonggor, Z. (2016). First nest and juvenile plumage descriptions of the ashy robin Heteromyias albispecularis of vogelkop Peninsula, West Papua. Kukila, 19, 53-59.

Orme, C.D.L., Davies, R.G., Burgess, M., Eigenbrod, F., Pickup, N., Olson, V.A., Webster, A.J., Ding, T.S., Rasmussen, P.C., Ridgely, R.S., Stattersfield, A.J., Bennett, P.M., Blackburn, T.M., Gaston, K.J. \& Owens, I.P.F. (2005). Global hotspots of species richness are not congruent with endemism or threat. Nature, 436, 1016-1019. doi: https://doi.org/10.1038/nature03850

Pratt, T.K. \& Beehler, B.M. (2015). Birds of New Guinea. $2^{\text {nd }}$ edition. Princeton University Press.

Roberts, C.M., McClean, C.J., Veron, J.E.N., Hawkins, J.P., Allen, G.R., McAllister, D.E., Mittermeier, C.G., Schueler, F.W., Spalding, M., Wells, F., Vynne, C. \& Werner, T.B. (2002). Marine biodiversity hotspots and conservation priorities for tropical reefs. Science, 295, 1280-1284. doi: https://doi.org/10.1126/science.1067728

Schrader, J., Moeljono, S., Keppel, G. \& Kreft, H. (2019a). Plants on small islands revisited: the effects of spatial scale and habitat quality on the species-area relationship. Ecography, 42, 1405-1414. doi: https://doi.org/10.1111/ecog.04512

Schrader, J., König, C., Moeljono, S., Pärtel, M. \& Kreft, H. (2019b). Requirements of plant species are linked to area and determine species pool and richness on small islands. Journal of Vegetation Science, 30, 599-609. doi: https://doi.org/10.1111/jvs.12758

Takeuchi, W. (2002). An ecological summary of the Raja Ampat vegetation. In: Report on a rapid ecological assessment of the Raja Ampat Islands, Papua, Eastern Indonesia, held October 30 November 22, 2002. pp. 97-108.

Takeuchi, W. (2003). A community-level floristic reconnaissance of the Raja Ampat islands in New Guinea. SIDA, 20, 1093-1138.

Wallace, A.R. (1869). The Malay Archipelago. London.

Weatherall, P., K. M. Marks, M. Jakobsson, T. Schmitt, S. Tani, J. E. Arndt, M. Rovere, et al. 2015. A new digital bathymetric model of the world's oceans. Earth and Space Science 2:331-345. doi: https://doi.org/10.1002/2015EA000107 